RASĀYAN J. Chem.

Vol. 13 | No. 3 |1606-1611| July - September | 2020

ISSN: 0974-1496 | e-ISSN: 0976-0083 | CODEN: RJCABP

\title{
ANTIBACTERIAL EFFECT OF PROTEIN AND PROTEIN HYDROLYSATES ISOLATED FROM BACTERIA Enterobacter hormaechei ASSOCIATED WITH MARINE ALGAE Sargassum sp.
}

\author{
N. Asmi ${ }^{1}$, A. Ahmad ${ }^{1, *}$, H. Karim ${ }^{2}$, M.N. Massi ${ }^{3}$, H. Natsir ${ }^{1}$, A. Karim ${ }^{1}$, \\ P. Taba ${ }^{1}$, Z. Dwyana ${ }^{4}$ and M. Ibrahim ${ }^{5}$ \\ ${ }^{1}$ Chemistry Department, Natural Science Faculty, Hasanuddin University, \\ Makassar 90245, Indonesia \\ ${ }^{2}$ Pharmacy Department, School of Pharmacy YAMASI, Makassar 90222, Indonesia \\ ${ }^{3}$ Microbiology Department, Medicine Faculty, Hasanuddin University, \\ Makassar 90245, Indonesia \\ ${ }^{4}$ Biology Department, Natural Science Faculty, Hasanuddin University, \\ Makassar 90245, Indonesia \\ ${ }^{5}$ Inc. Ismut Fitomedika Indonesia, Makassar 90224, Indonesia \\ *E-mail: ahyarahmad@gmail.com
}

\begin{abstract}
This research study is about the antibacterial potential of protein and its hydrolysates isolated from bacteria Enterobacter hormaechei associated with marine algae. The protein was isolated using a fractionation method with ammonium sulphate. The fractions were pre-purified through dialysis with buffer Tris $\mathrm{HCl}$. Protein hydrolysates were obtained through hydrolysis using the pepsin enzyme. Antibacterial activity was conducted using Escherichia coli and Staphylococcus aureus. The inhibition zone was observed after incubation for $24 \mathrm{~h}, 48 \mathrm{~h}$, and $72 \mathrm{~h}$ at $37^{\circ} \mathrm{C}$. Results show that F1 fraction of protein hydrolysates had the highest activity against Escherichia coli and Staphylococcus aureus at $72 \mathrm{~h}$ with inhibition zones of $16.30 \pm 0.03 \mathrm{~mm}$ and $16.70 \pm 0.03 \mathrm{~mm}$, respectively. Protein hydrolysates had higher inhibitory activity than the protein fraction, so it provides an information base for further study on the antibacterial drugs from bacteria associated with marine algae.

Keywords: Antibacterial, Brown Algae, Enterobacter hormaechei, Protein, Protein Hydrolysates.
\end{abstract}

(c) RASĀYAN. All rights reserved

\section{INTRODUCTION}

Marine organisms have rich and unique chemical substances compared to terrestrial organisms. ${ }^{1}$ Marine algae are one of the abundant biological resources and rich in various bioactive activity. ${ }^{2}$ Improved microbiological techniques in the last few decades have developed rapidly to help identify phylogenetic affiliations of the community of bacteria associated with marine algae. However, there is inadequate data about the functional relationship between marine algae-bacteria interactions. ${ }^{3}$ Future studies must integrate diverse aspects in the biological field. Many eukaryote organisms are closely related to bacteria, which allows marine algae to expand their physiological abilities. Although chemical interactions related to marine algae-bacteria relationships are based on the transition of nutrients, minerals, and secondary metabolite compounds. However, this relationship pattern has not been thoroughly explored. ${ }^{4,5}$

Isolation of symbiotic bacteria from marine algae have abundant potential. The presence of these bacteria is thought to be a result of a form of mutual symbiosis. Bacteria utilize marine algae as a source of nutrition, while bacteria help the growth of marine algae and protect algae against pathogens by producing bioactive compounds. ${ }^{4,5}$

The study of protein and its hydrolysates are research trends that play an essential role in the pharmaceutical and nutraceutical field. ${ }^{6}$ One method to utilize bacterial protein is through enzymatic protein hydrolysis.

Rasayan J. Chem., 13(3), 1606-1611(2020)

http://dx.doi.org/10.31788/RJC.2020.1335696

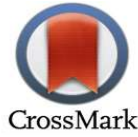


RASĀYAN J. Chem.

Vol. 13 | No. 3 |1606-1611| July - September | 2020

Enzymatic protein hydrolysis has an advantage over protein hydrolysis with acids and alkalis because the resulting peptide product has a composition and sequence of amino acids that are specific according to the type of protease used. ${ }^{7}$ Although studies of protein hydrolysis have been widely developed..$^{8,9,10,11}$ isolation of protein and its hydrolysates from symbiotic bacteria from marine algae is not widely reported. In this study, protein isolation and hydrolysis has been carried out, and the antibacterial activity was screened.

\section{Materials}

\section{EXPERIMENTAL}

The isolate bacteria Enterobacter hormaechei associate with Sargassum sp., BHIB medium, $\mathrm{NH}_{2} \mathrm{C}\left(\mathrm{CH}_{2} \mathrm{OH}\right)_{3} 0.1 \mathrm{M} \mathrm{pH} 8.3$, Natrium chloride $2 \mathrm{M}$, Calcium chloride $0.01 \mathrm{M}, \beta$-mercaptoethanol 1\%; Triton X-100 0.5\%, $\mathrm{HCl} 1 \mathrm{M}$, pepsin enzyme, $\left(\mathrm{NH}_{4}\right)_{2} \mathrm{SO}_{4}$, seawater, sterile water, Escherichia coli, Staphylococcus aureus, and shrimp A. salina Leach.

\section{Sample Preparation}

Marine algae were collected from Lae-Lae Island, Makassar, Province of South Sulawesi, Republic of Indonesia. The isolate of bacteria Enterobacter hormaechei associated with Sargassum sp. was collected as per previous research. ${ }^{12}$

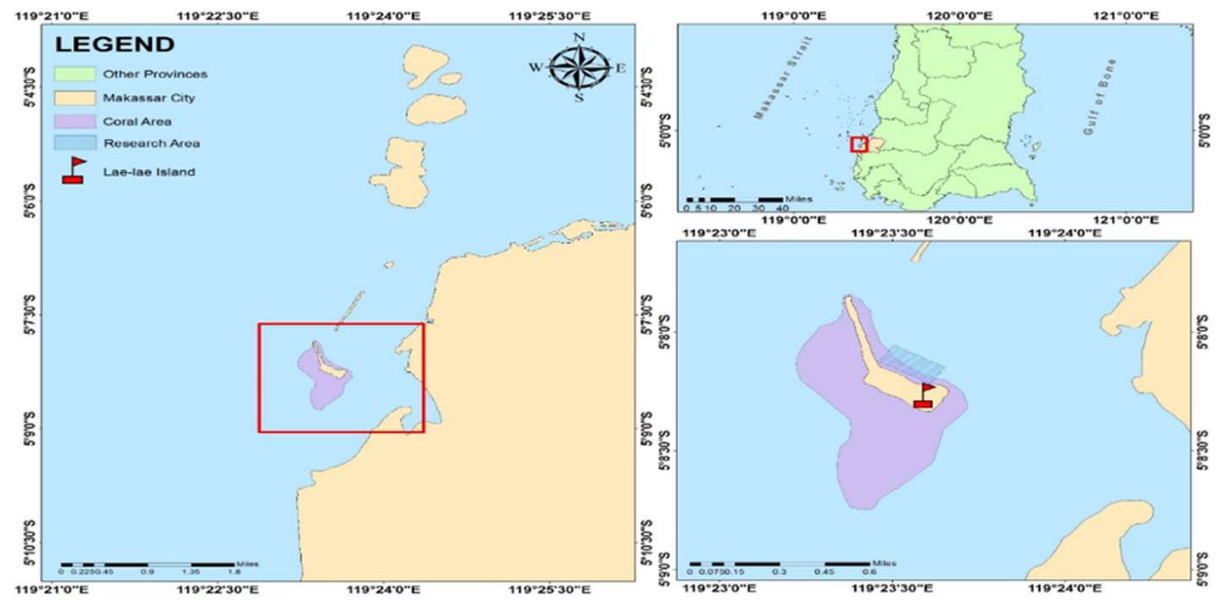

\section{Isolation of Protein}

Fig.-1: Sampling Sites of Marine Algae Sargassum sp. Obtained From Lae-Lae Island

The isolate bacteria that had been refreshed on the BHIB medium were taken $10 \%$ into the new inoculum medium. The bacteria were then incubated at $180 \mathrm{r} / \mathrm{min}, 37^{\circ} \mathrm{C}$ for 24 hours. The inoculate is centrifuged until a cell paste is obtained. Cell lysis was performed using buffer A solution followed by a frozen/thawed and sonication process to get a crude extract of protein. ${ }^{13,14}$ The crude extract of protein is then carried out fractionation at various levels saturation of ammonium sulphate, and protein fractions were dialyzed.

\section{Hydrolysis of Protein}

Protein hydrolysates obtained by hydrolysis using the enzyme pepsin ${ }^{15}$, at $37^{\circ} \mathrm{C}, \mathrm{pH} 2.0$, comparison of enzyme-substrate 1:3, for $90 \mathrm{~min}$. After hydrolysis, the hydrolysates were inserted in boiling water for 10 min. The hydrolysates which had been collected were centrifuged at $10000 \mathrm{r} / \mathrm{min}$, at $4^{\circ} \mathrm{C}$ for $20 \mathrm{~min}$.

\section{Determination of Protein Content}

Protein content was determined at $280 \mathrm{~nm}\left(A_{280}\right)$. The spectrophotometer was set the wavelength to $280 \mathrm{~nm}$ by using NanoDrop ${ }^{\mathrm{TM}}$ 2000/2000c Spectrophotometers (Thermo Ficher Scientific). The absorbance of protein standard and sample was measured.

\section{Antibacterial Activity Assay}

The activity of antibacterial against $E$. coli and $S$. aureus were conducted with the agar diffusion method following standard procedures. ${ }^{16}$ The paper discs were dipped in protein fraction or protein hydrolysates 
RASĀYAN J. Chem.

Vol. 13 | No. 3 |1606-1611| July - September | 2020

and then placed on the surface of an MHA plate containing $0.5 \mathrm{~mL}$ cultures $\left(1 \times 10^{4}\right.$ cell $\left./ \mathrm{mL}\right)$ of each test pathogenic bacterium. The inhibition zone was determined after incubation for 24,48 , and $72 \mathrm{~h}$ at $37^{\circ} \mathrm{C}$.

\section{Isolation of Protein}

\section{RESULTS AND DISCUSSION}

The bacteria Enterobacter hormaechei was cultured according to the optimum production time by following the previous research ${ }^{12}$. Cell culture in Brain-heart Infusion Broth (BHIB) medium was centrifuged at 5000 $\mathrm{r} / \mathrm{min}, 4^{\circ} \mathrm{C}$ for $30 \mathrm{~min}$. The cell pellet was then dissolved in $250 \mathrm{~mL}$ of buffer solution. The cells were frozen/thawed, followed by ultrasonication by short cycles of 30-sec duration and 20 min total working time. ${ }^{14}$ The temperature during the process was controlled by an ice bath. The cell lysate was then centrifuged again to obtain the crude extract. Purification with $\left(\mathrm{NH}_{4}\right)_{2} \mathrm{SO}_{4}$ is one of the initial methods of purification of proteins. The crude extract was fractionated at a saturation level of $\left(\mathrm{NH}_{4}\right)_{2} \mathrm{SO}_{4}$. Purification process followed by dialysis through a semipermeable membrane. The protein content of dialysate (Fig.-2) was determined using the $A_{280}$ method by NanoDrop ${ }^{\mathrm{TM}}$ 2000/2000c Spectrophotometers (Thermo Ficher Scientific).

\section{Hydrolysis of Protein}

Protein hydrolysis was done using the pepsin enzyme at optimum conditions. Hydrolysis lasted for $90 \mathrm{~min}$ at $37^{\circ} \mathrm{C}, \mathrm{pH} 2$. Figure-2 shows data on decreased protein levels after hydrolysis.

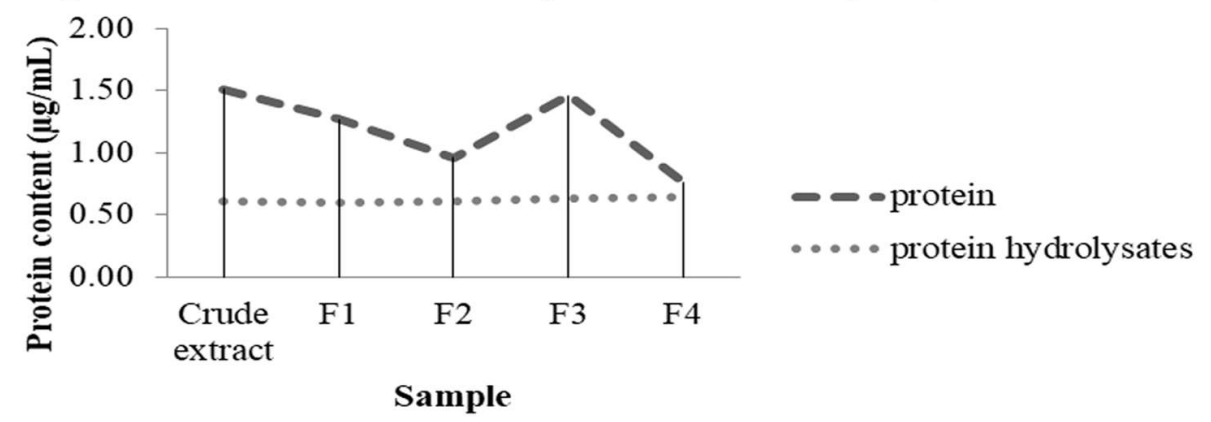

Fig.-2: Protein Content of Protein and Protein Hydrolysates From Bacteria Enterobacter hormaechei

\section{Antibacterial Activity}

Most antibacterials are produced through enzymatic hydrolysis of proteins from various sources. This research used bacteria as a source of protein. The results of the inhibition zone measurement of protein and its hydrolysates against the growth of both pathogenic bacteria after being incubated for 24,48 , and $72 \mathrm{~h}$ are shown in Fig.-3 and Fig.-4. As seen in Fig.-3, the antibacterial activity of the protein fraction did not give significant results. The highest inhibitory zone against Escherichia coli and Staphylococcus aureus was shown by the F4 fraction after incubation for $72 \mathrm{~h}$, with a diameter of inhibition zone of $7.00 \pm 0.06$ $\mathrm{mm}$ and $7.40 \pm 0.02 \mathrm{~mm}$, respectively.

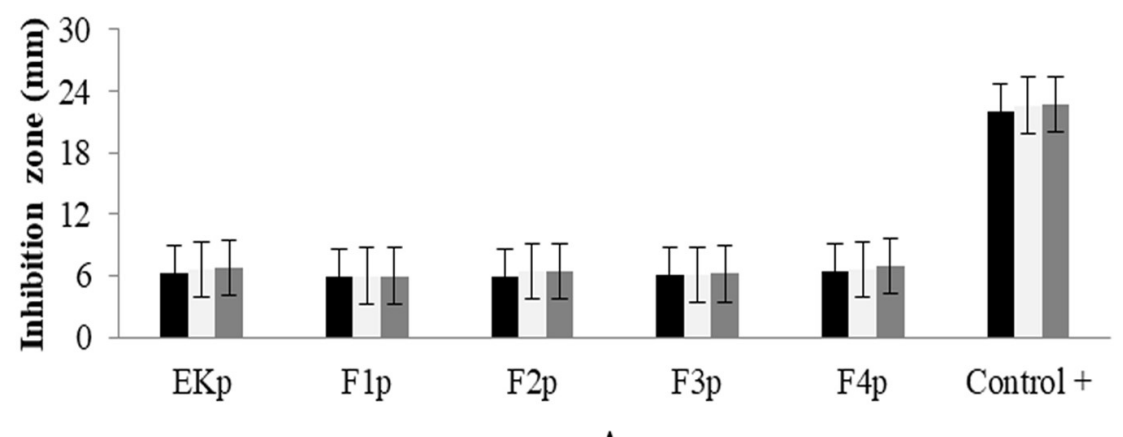

A 
RASĀYAN J. Chem.

Vol. 13 | No. 3 |1606-1611| July - September | 2020

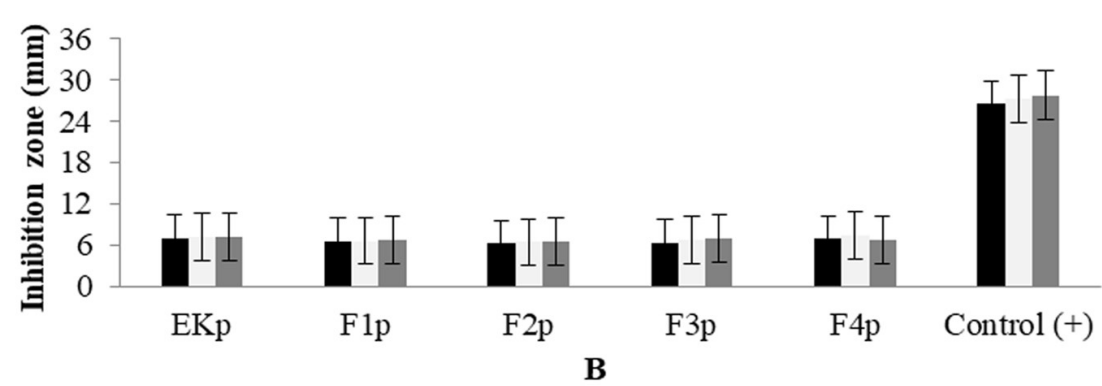

Fig.-3: Diameter Inhibition Zones of Protein Fraction against Escherichia coli (A) and Staphylococcus aureus (B) for 24, 48, and 72 hours. (Note: EKp: Crude extract protein; F1p-F4p: Fraction of protein). The value is mean \pm SD.

Figure-4 shows fragments of protein hydrolysates against Escherichia coli and Staphylococcus aureus. The highest antibacterial activity after incubation for $72 \mathrm{~h}$ was obtained from the protein hydrolysates F1 fraction with a diameter of inhibition zone of $16.30 \pm 0.03 \mathrm{~mm}$ and $16.70 \pm 0.03 \mathrm{~mm}$, respectively. The data of antibacterial activity shows that the protein hydrolysates provide significant results in inhibiting both pathogenic bacteria. The long peptide chain on the protein is broken down into smaller peptide fragments so that the hydrolysed protein can penetrate the cell wall of pathogenic bacteria ${ }^{17}$.
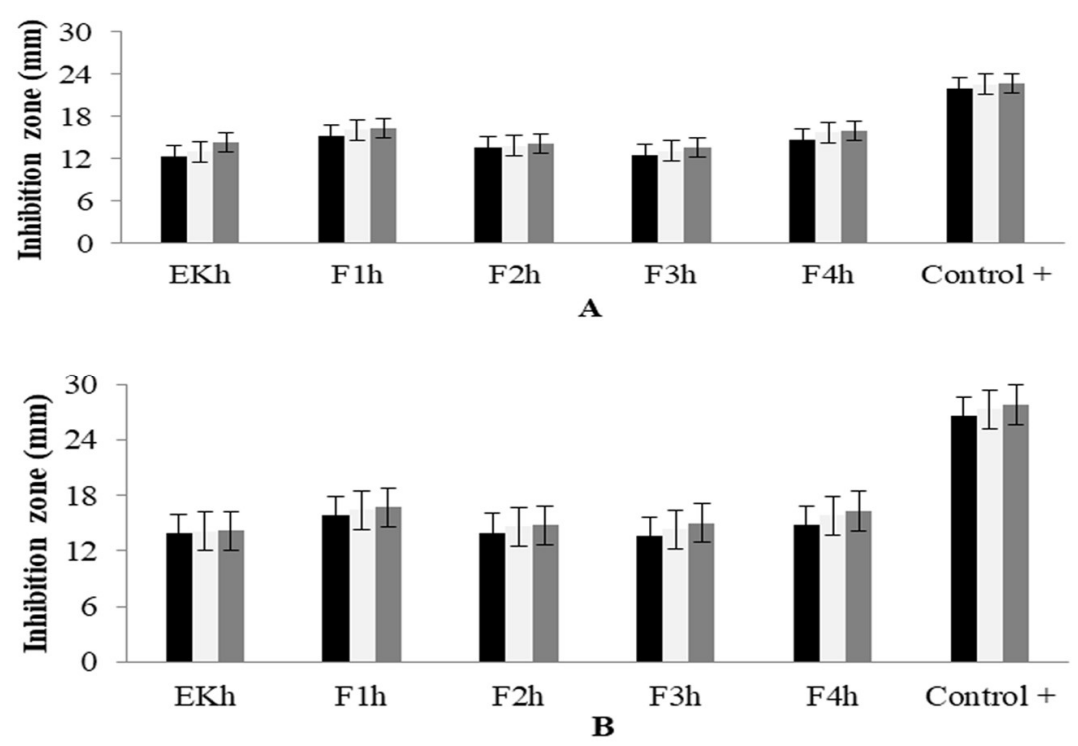

Fig.-4: Diameter Inhibition Zones of Protein Hydrolysates against Escherichia coli (A) and Staphylococcus aureus (B) for 24, 48, and 72 hours. (Note: EKh: Crude Extract Protein after Hydrolysis; F1h-F4h: Fraction of Protein after hydrolysis). The Value is mean $\pm \mathrm{SD}$.
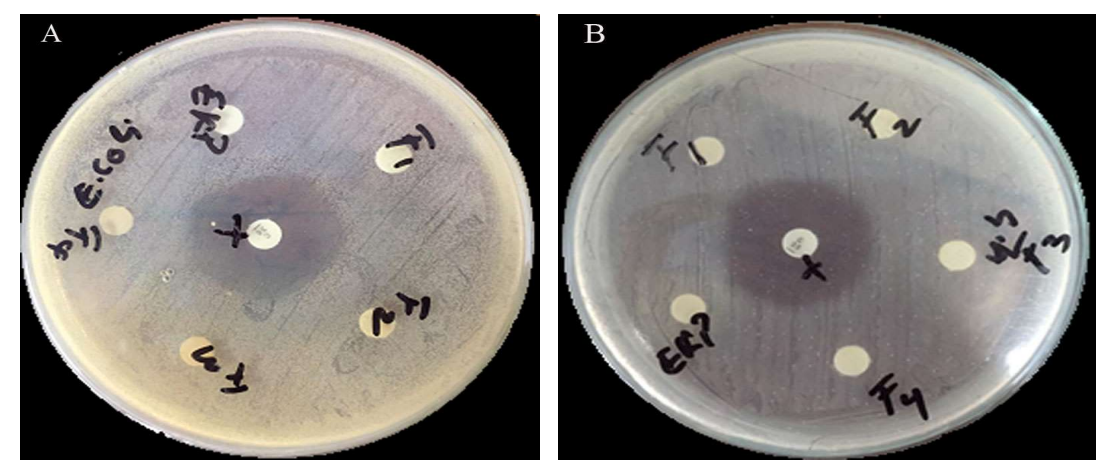

Fig.-5: Visualization of Diameter Inhibition Zones of Protein Fraction against E. coli (A) and S. aureus (B). (Note: EKp: Crude Extract Protein; F1-F4: Fraction of Protein). 
RASĀYAN J. Chem.

Vol. 13 | No. 3 |1606-1611| July - September | 2020
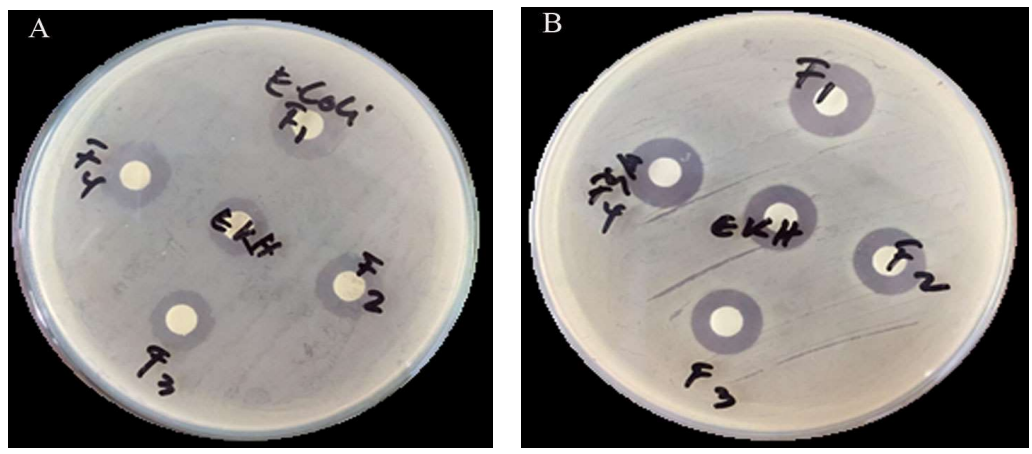

Fig.-6: Visualization of Diameter Inhibition Zones of Protein Hydrolysates against E. coli (A) and S. aureus (B). (Note: EKh: Crude Extract Protein after Hydrolysis; F1h-F4h: Fraction of Protein after Hydrolysis).

\section{CONCLUSION}

Researches about substances from bacteria symbiont associated with marine algae opened insights into the scientific perspectives related to the discovery of new drugs. From this result, the exploration of protein and its hydrolysates shows potential outcomes in the development of the antibacterial substance. In this study, the highest antibacterial activity against Escherichia coli and Staphylococcus aureus was shown by protein hydrolysates, resulting in the formation of inhibition zones $16.30 \pm 0.03 \mathrm{~mm}$ and $16.70 \pm 0.03 \mathrm{~mm}$ in diameter, respectively. These studies found protein hydrolysates showed better efficacy than protein fraction against both bacteria pathogen.

\section{ACKNOWLEDGMENT}

KEMENRISTEKDIKTI funds this research through the scheme PMDSU research grants, 3rd Year 2020 by Contract No. 1517/UN4.22/PT.01.03/2020. This research is also supported by the program of World Class University, managed by Bandung Institute of Technology, SABBATICAL LEAVE, and Enhance International Publication (EIP) Program by KEMENRISTEKDIKTI.

\section{REFERENCES}

1. M.A Artasasta, Yanwirasti, M. Taher, A. Djamaan and D. Handayani, Rasayan Journal of Chemistry, 12(3),1463(2019), DOI:10.31788/RJC.2019.1235284

2. S.H. Eom, Y.M. Kim and S.K. Kim, Food and Chemical Toxicology, 50(9), 3251(2012), DOI:10.1016/j.fct.2012.06.028

3. M.M.F. de Mesquita, M.A.C. Crapez, V.L. Teixeira and D.N. Cavalcanti, Journal of Applied Phycology, 31,867(2019), DOI:10.1007/s10811-018-1573-4

4. J. Hollants, F. Leliaert, O.D. Clerck and A. Willems, FEMS Microbiology Ecology, 83(1), 11(2012), DOI:10.1111/j.1574-6941.2012.01446.x

5. F. Goecke, A. Labes, J. Wiese and J.F. Imhoff, Marine Ecology Progress Series, 409, 267(2010), DOI: $10.3354 / \mathrm{meps} 08607$

6. E.C. Li-Chan, Current Opinion in Food Science, 1, 28(2015), DOI:10.1016/j.cofs.2014.09.005

7. O.L. Tavano, Journal of Molecular Catalysis B: Enzymatic, 90, 1(2013), DOI: 10.1016/j.molcatb.2013.01.011

8. K. Ratnayani, I.K. Suter, N.S. Antara and I.N.K. Putra, Indonesian Journal of Chemistry 19(4), 900(2019), DOI: 10.22146/ijc.37513

9. G. Kaur, T.P. Singh and R.K. Malik, Brazilian Journal of Microbiology, 44(11), 63(2013), DOI: $10.1590 / \mathrm{S} 1517-83822013005000025$

10. R.C.R. Martinez, C.D. Staliano, A.D.S. Vieira, M.L.M. Villarreal, S.D. Todorov, S.M.I. Saad and M.G.D.B. Franco, Food Microbiology, 48,143(2015), DOI:10.1016/j.fm.2014.12.010

11. S.G. Zhao, J.Z. Han, X.M. Bie, Z.X. Lu, C. Zhang and F.X. Lv, Journal of Agricultural and Food Chemistry, 64(13), 2754(2016), DOI:10.1021/acs.jafc.5b05717 
RASĀYAN J. Chem.

Vol. 13 | No. 3 |1606-1611| July - September | 2020

12. N. Asmi, A. Ahmad, M.N. Massi and H. Natsir, International Research Journal of Pharmacy 10(6), 10(2019), DOI: 10.7897/2230-8407.1006195

13. A. Trevilov, M. Imendoerffer, G. Sekot, F. Strobl, A. Jungbauer and R. Hahn, Journal of Biotechnology 207, 21(2015), DOI:10.1016/j.jbiotec.2015.04.023

14. D. Liu, X. Zeng, D. Sun and Z. Han, Innovative Food Science and Emerging Technologies, 18, 132(2013), DOI:10.1016/j.cofs.2014.09.005

15. B. Zhang and X. Zhang, Biotechnology Progress, 29(5), 1230(2013), DOI:10.1002/btpr.1769

16. A.A. Mostafa, A.A. Al-Askara, K.S. Almaarya, T.M. Dawouda, E.N. Sholkamya and M.M. Bakri, Saudi Journal of Biological Sciences, 25(1),361(2018), DOI:10.1016/j.sjbs.2017.02.004

17. J. Thundimadathil, Joumal of Amino Acids, Article ID 967347 (2012), DOI:10.1155/2012/967347.

[RJC-5696/2020] 